\title{
Comparing the productivity of Norwegian and some Nordic and UK container ports - an application of Malmquist productivity index
}

\author{
Halvor Schøyen* \\ Buskerud and Vestfold University College, \\ P.O. Box 4, NO-3199 Borre, Norway \\ Email: hs@hbv.no \\ *Corresponding author

\section{James Odeck} \\ Molde University College, \\ P.O. Box 2110, NO-6402, Molde, Norway \\ Email: james.odeck@vegvesen.no
}

\begin{abstract}
This article measures productivity changes during 2009 - 2014 of the six largest Norwegian container ports against 14 similar small- and medium-sized ports in the Nordic countries and the UK. The approach used is the data envelopment analysis (DEA)-based Malmquist productivity change index (MPI), which carries out a decomposition isolating the technical progress of the efficiency improvement. The major findings are: 1) the sampled Norwegian ports seem to perform better than their international counterparts in terms of efficiency scores; 2) when productivity growth over time is considered, the Norwegian ports appear to be overperformers but a statistical test proves that they are not; 3 ) overall, total productivity increased by approximately $0.6 \%$ per year for all ports considered and this progress is explained more by technological improvements and less by efficiency change, which declined during the period studied. This study provides Norwegian decision makers with new information regarding the performance of Norway's container port industry.
\end{abstract}

Keywords: container ports; productivity; port performance; data envelopment analysis; DEA; Malmquist productivity index; MPI.

Reference to this paper should be made as follows: Schøyen, H. and Odeck, J. (2017) 'Comparing the productivity of Norwegian and some Nordic and UK container ports - an application of Malmquist productivity index', Int. J. Shipping and Transport Logistics, Vol. 9, No. 2, pp.234-256.

Biographical notes: Halvor Schøyen is an Associate Professor of Maritime Logistics at Buskerud and Vestfold University College, Norway. His research interest are in shipping and transport which includes all areas but specifically energy use and energy efficiency in maritime logistics, integration of port and terminal operations with shipping operations and supply chain management. He has published papers in journals such as Ocean Engineering, Research in Transport Business and Management, Maritime Policy \& Management, Maritime Economics \& Logistics and Journal of Transport Geography. 


\begin{abstract}
James Odeck is a Professor of Applied Economics and specialises in transport economics, production economics and performance measurement. His research interests include all areas but specifically, valuation of impacts, benefit-cost analysis, road pricing, and price elasticities in transport and cost estimations of infrastructure projects. In production and performance measurement, his research interests include efficiency and productivity measurement using econometric methods such as data envelopment analysis and stochastic frontier analysis. He teaches among others at Molde University College, Norway and The Norwegian University of Science and Technology. He is employed as a Senior Research Economist at the Norwegian Public Roads Administration.
\end{abstract}

\title{
1 Introduction
}

Ports are critically important to a well-functioning transportation system and are an integral part of supply chains (Meeresman and Van de Voorde, 2010). Ports are the link between sea transport and all other forms of transport and perform important trade function by facilitating linkages between producers and consumers.

Governments and port authorities are constantly seeking to improve the efficiency and productivity growth of ports. Thus, measuring and monitoring performance of ports may reveal the inefficiencies, areas of low productivity and ways to improve these weaknesses. In the long term, a performance assessment may improve the performance of ports as providers of transportation services. Increased containerised freight import and export volumes, larger feeder vessels and new roads has resulted in a Norwegian national policy call for fewer and more specialised ports (NTP, 2010). Further, revisions of the Norwegian Seaport Act as from January 2010 deregulate and liberalise how port services can be organised, facilitating for ports to act more as logistics nodes in supply chains. This paper contributes to identify recent key underlying developments in the Nordic and UK container gateway port system, by empirically assessing productivity changes over time and their operational causes. The main contribution of this paper is that it is the first to consider productivity indices of the Norwegian seaport industry.

Studies of port efficiency have grown in the literature of transportation and public utilities (see e.g. Panayides et al., 2009; Odeck and Bråthen, 2012; Woo et al., 2012) for recent reviews. However, studies of port productivities, i.e., how ports perform relative to each other over time, are less frequent in the literature. Furthermore, studies that compare the productivity growth of Norwegian container ports by themselves or in comparison to other comparable ports in the region, i.e., gateway ports in the Nordic countries and the UK, are lacking in the literature. Gateway container ports are nodal points for the entrance to and exit from a region, a country or a continent and imply a shift between the maritime mode and various land modes (Rodrigue et al., 2006). Gateway ports have in common that sea-sea transhipment ratio is low, in contrast to transhipment hubs (Notteboom, 2010). Thus, Norwegian authorities concerned with the performance of container ports do not know how their container ports perform relative to each other within the same region or relative to other comparable ports in other regions or countries.

This paper addresses the above shortcomings in the literature by measuring the productivity growth of Norwegian container ports in comparison to comparable gateways in the Nordic countries and the UK. This paper thus contributes to the literature of seaport 
productivity by providing the knowledge on the productivity of Norwegian ports that has been lacking in the literature. We address the following three research questions:

1 What is the potential for productivity improvements among the principal Norwegian container ports?

2 Do the Norwegian container ports over time perform better or worse than comparable international ones?

3 What productivity components explain the derived productivity progress/decline: efficiency change, technical innovation or scale improvements?

Supply chains comprise a multiple of actors with different interests, and it is difficult for container ports to gauge the performance of their activities on a supply chain-wide basis. Lai et al. (2002) identified the following three dimensions of supply chain performance in transport logistics:

1 service effectiveness for shippers

2 operations efficiency for transport logistics service providers (e.g. container ports)

3 service effectiveness for consignees.

Their empirical study on supply chain performance found the above-mentioned three dimensions to be positively highly correlated. This paper addresses facets of operations efficiency change over time.

The approach that we use to measure the productivity of container ports is the Malmquist productivity index (MPI), based on the data envelopment analysis (DEA). Productivity change and its decompositions can be similarly estimated by the Luenberger approach. We warn that researchers have shown that the MPI approach overestimates the productivity change compared to the Luenberger approach (Haralambides et al., 2010), thus in applied productivity analysis one should be careful of misjudging differences in magnitudes of empirical results that are only to be explained by the employment of different families of productivity indices. The DEA measures the frontiers from which efficiencies and, hence, productivity change over time can be measured (see for instance Färe et al., 1994). The DEA approach is the most common method in the literature of efficiency measurement of seaports (see Panayides et al., 2009; Odeck and Bråthen, 2012). The MPI can be equally based on a stochastic frontier analysis (SFA) (see for instance, Coelli, 1996). The choice to develop production frontiers and study productivity growth by using DEA rather than the SFA-based MPI approaches was dictated by two motives:

1 the family of DEA models do not impose any assumption on the form of the production function or error structure, as for SFA

2 to remain consistent with the majority of studies on productivity growth of container ports so that the findings of this paper are comparable as far as the methodological approach is concerned (Odeck and Bråthen, 2012; Woo et al., 2011).

The remainder of this paper is organised as follows. Section 2 is a literature review of productivity assessments of container ports; Section 3 presents the theoretical model used to assess productivity changes for container ports; Section 4 presents the data; Section 5 
presents the empirical results and Section 6 discusses implications and concludes the paper.

\section{Literature review}

We searched the literature for studies on the productivity of container ports using the MPI based on a DEA. While the search uncovered several efficiency studies of container ports based on either DEA or SFA, it retrieved only nine studies that used the DEA-based MPI to explore the productivity change of container ports from one period to the next. A summary of these papers follows.

Estache et al. (2004), in their seminal paper, investigated the productivity changes of 11 Mexican ports over the period 1996-1999. They applied a DEA-based MPI based on both constant returns to scale (CRS) and variable returns to scale (VRS) technology. The measure for output was tonnage handled while inputs were berth lengths and number of port workers. Their conclusions were that the MPI increased in the period for the majority of ports, and the gains were attributed to two factors: adoption of new technologies and improvements in technical efficiency. Guerrero and Rivera (2009) followed up on the study of Estache et al. (2004) by investigating the productivity growth for seven Mexican container ports for the period 2000 to 2007 using the DEA-based MPI. The output was number of 20 feet equivalent container units (TEU) handled, while inputs were berth lengths, terminal areas and amount of container handling equipment. They concluded that there had been MPI increases in five of the seven ports studied, and the increases were due to three factors: the adoption of new technologies, improvements in technical efficiencies with regards to the operations and improvement in scale efficiencies. They further concluded that the productivity increases were greater for the medium sized container terminals than for the hub terminals.

Liu et al. (2008) applied a DEA-based MPI to evaluate the productivity of 45 Chinese container terminals of various sizes. They used the number of TEUs handled as the only output, while inputs were berth lengths and the amount of container handling equipment. They found that the average terminal experienced a decline in technological innovation concurrently with a total productivity progress, possibly explained by efficiency improvements. Further, the authors tested for differences in performance between domestic and foreign-Chinese joint ventures. The results revealed no significant differences in the MPIs between these two groups. Next, Fu et al. (2009) investigated the productivity growth of the ten largest Chinese container ports over the period 2001-2006 by applying a DEA-based MPI approach. The outputs were container throughput (in number of TEUs) and the number of liner ship calls into or out of the port. The inputs were berth lengths, the number of container gantry cranes and the GDP of the hinterland. They concluded that the main influence on productivity growth is technological change.

Since 2009, five more papers on the productivity of ports using MPI based on DEA have appeared in the literature. The first is by Cheon et al. $(2009,2010)$, who examined the productivity growth of 98 major world container ports over the period 1991-2004. Lozano (2009) assessed the productivity developments of 50 state owned ports (not only containerised freight) in Spain over the period 2002-2006. Al-Eraqi et al. (2009) analysed 22 container ports in the Middle East over the period 2000-2005. Barros et al. (2011) provided a review of the status quo for productivity measurements of ports and further studied a sample of Middle Eastern and East African ports. Lastly, Song and 
Cui (2014) analysed the productivity developments overt the period 2006-2011 of 26 container terminals in Chinese ports by using container throughput as the output variable and the three input variables number of staff and workers, number of bridge cranes and quay lengths. The major source of productivity growth was technical progress rather than an improvement in technical efficiency.

These studies vary in the inputs and outputs used, and vary substantially by the number of ports sampled and the port sizes with respect to container throughput. Notably, the studies do not converge on a conclusion regarding which, if any, of the productivity components technological changes or technical efficiency changes determines overall productivity change, neither for ports in general nor for container ports in particular. In this paper, we expand on the previous research by adopting the DEA-based MPI to analyse the productivity changes in a sample of Nordic and UK container gateway ports. Surprisingly, none of the studies cited above has focused on gateway container seaports, given their peculiarities described above.

\section{Methodological approach}

The approach that we use to explore productivity of container ports is the DEA-based MPI. DEA measures the efficiency of a given unit of production (container port) in terms of its distance to a given frontier. The frontier is composed of the best performing units of production. Thus, if a unit of production on the frontier is efficient, its efficiency score will be 1 , meaning that it is $100 \%$ efficient. Otherwise, the efficiency score will be less than 1, meaning that the unit of production is inefficient. A unit of production's inefficiency is measured by subtracting its efficiency score from 1; multiplying this result by one hundred gives the percentage potential for an efficiency improvement. The distance to the frontier (or the measure of efficiency) is defined as $\mathrm{d}^{t}\left(\mathrm{x}^{\mathrm{t}}, \mathrm{y}^{t}\right)$. This measure assumes that efficiency is constructed with reference to the frontier in the same period, $t$. In the next period $t+1$, the efficiency measure would be $d^{t+1}\left(x^{t+1}, y^{t+1}\right)$. However, the efficiency measure can also be constructed relative to a frontier in the previous or the next period, in which case the efficiency scores would be $\mathrm{d}^{\mathrm{t}}\left(\mathrm{x}^{\mathrm{t}+1}, \mathrm{y}^{\mathrm{t}+1}\right)$ or $\mathrm{d}^{\mathrm{t+1}}\left(\mathrm{x}^{\mathrm{t}}, \mathrm{y}^{\mathrm{t}}\right)$, respectively. An interesting feature of these efficiency measures is that while $\mathrm{d}^{\mathrm{t}}\left(\mathrm{x}^{\mathrm{t}}, \mathrm{y}^{\mathrm{t}}\right)$ and $\mathrm{d}^{\mathrm{t}+1}\left(\mathrm{x}^{\mathrm{t}+1}, \mathrm{y}^{\mathrm{t}+1}\right)$ cannot be greater than $1, \mathrm{~d}^{\mathrm{t}}\left(\mathrm{x}^{\mathrm{t}+1}, \mathrm{y}^{\mathrm{t}+1}\right)$ and $\mathrm{d}^{\mathrm{t}+1}\left(\mathrm{x}^{\mathrm{t}+}, \mathrm{y}^{\mathrm{t}}\right)$ can be greater than 1 if there has been technical progress or a technical decline.

To enhance the understanding of the DEA efficiency measurements, Figure 1 illustrates the above concepts for a situation with a single output and a single input, and the frontiers from which efficiencies are being measured are $\mathrm{F}^{\mathrm{t}}$ and $\mathrm{F}^{\mathrm{t}+1}$ representing CRS frontiers in period $t$ and period $t+1$, respectively. Here we have assumed that the frontier in period $t+1$ is greater than that in period $t$, but the opposite is quite possible if the technology has declined, i.e., the frontier in period $t+1$ fell below that of period $t$.

Consider now a production unit (a gateway port) observed in period $t$ and period $t+1$ and represented by points $\left(\mathrm{x}^{\mathrm{t}}, \mathrm{y}^{\mathrm{t}}\right)$ and $\left(\mathrm{x}^{\mathrm{t}+1}, \mathrm{y}^{\mathrm{t}+1}\right)$ respectively. Next, we are interested in measuring the output-oriented efficiency of this unit, which is the degree to which the output of this unit could increase, given the inputs, if the unit was projected to the frontier. This unit of production is clearly positioned below the frontier of period $t$, meaning that it is not technically efficient. This unit's technical output-oriented efficiency score relative to the frontier in period $t$ is defined as the relative distance to the frontier $\mathrm{F}^{\mathrm{t}}$ and is calculated as $\mathrm{d}^{\mathrm{t}}\left(\mathrm{x}^{\mathrm{t}}, \mathrm{y}^{\mathrm{t}}\right)=0 \mathrm{~A} / 0 \mathrm{~B}=\mathrm{y}^{\mathrm{t}, \mathrm{t}} / \mathrm{y}^{\mathrm{t}}<1$. In the period $\mathrm{t}+1$, its efficiency 
score relative to frontier of the period $\mathrm{F}^{\mathrm{t}+1}$, is calculated as $\mathrm{d}^{\mathrm{t}+1}\left(\mathrm{x}^{\mathrm{t}+1}, \mathrm{y}^{\mathrm{t}+1}\right)=0 \mathrm{E} / \mathrm{EF}=$ $\mathrm{y}^{\mathrm{t}+1} / \mathrm{y}^{\mathrm{t}+1, \mathrm{t}+1}<1$. We have as yet measured the efficiency of observations of one period relative to the frontier of the same period. It is possible to measure efficiency relative to an adjacent period: the efficiency of observation in period $t,\left(x^{t}, y^{t}\right)$, relative to the frontier in period $\mathrm{t}+1, \mathrm{~F}^{\mathrm{t}+1}$, is $\mathrm{d}^{\mathrm{t}+1}\left(\mathrm{x}^{\mathrm{t}}, \mathrm{y}^{\mathrm{t}}\right)=0 \mathrm{~A} / 0 \mathrm{D}=\mathrm{y}^{\mathrm{t}} / \mathrm{y}^{\mathrm{t}+1, \mathrm{t}}<1$. The efficiency measure of an observation in period $\mathrm{t}+1$ relative to the frontier in period $\mathrm{t}, \mathrm{F}^{\mathrm{t}}$, is calculated as $\mathrm{d}^{\mathrm{t}}\left(\mathrm{x}^{\mathrm{t}+1}, \mathrm{y}^{\mathrm{t}+1}\right)=0 \mathrm{E} / 0 \mathrm{C}=\mathrm{y}^{\mathrm{t}+1} / \mathrm{y}^{\mathrm{t}, t+1}>1$. This measure is now greater than 1 for the simple reason that the observations in the period $t+1$ are beyond the frontier of period $t$, meaning the unit has progressed relative to the frontier in the previous period.

Figure 1 Illustrating the workings of DEA and Malmquist productivity index (see online version for colours)

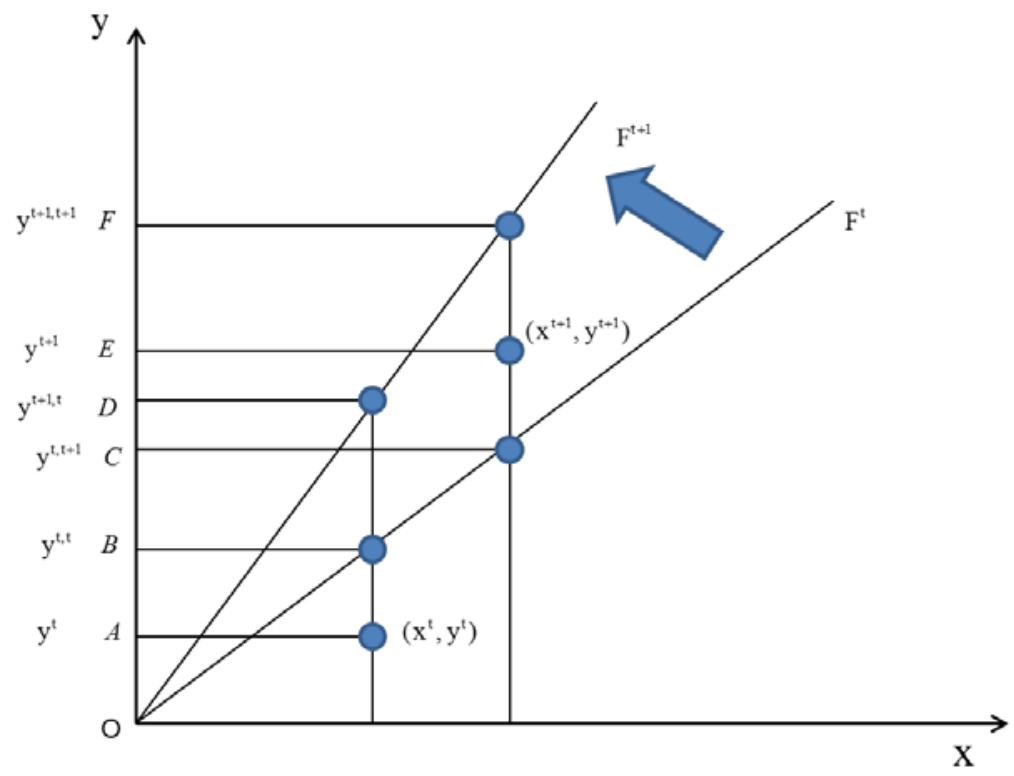

Based on the above concepts of the workings of DEA, the MPI can now be defined. The MPI is an index that measures productivity growth defined as improved efficiency between two adjacent periods relative to a given frontier. Thus, using the definitions of the different DEA measures above, the MPI to measure productivity growth from period $t$ to period $t+1$ using the frontier of period $t$ is expressed as

$$
\operatorname{MPI}\left(x^{t}, y^{t}, x^{t+1}, y^{t+1}\right)=\frac{d^{t}\left(x^{t+1}, y^{t+1}\right)}{d^{t}\left(x^{t}, y^{t}\right)}
$$

The above measure of the MPI can alternatively be constructed using the technology at period $t+1$, which can give a different result. To avoid the ambiguity of choosing one of the alternative reference periods as the appropriate measure of MPI, Färe et al. (1994) defined the output-based MPI as a geometric mean of the two alternative measures (i.e., using $t$ and $t+1$ as the reference frontier): 


$$
\operatorname{MPI}\left(\mathrm{x}^{\mathrm{t}+1}, \mathrm{y}^{\mathrm{t}+1}, \mathrm{x}^{\mathrm{t}}, \mathrm{y}^{\mathrm{t}}\right)=\left[\frac{\mathrm{d}^{\mathrm{t}}\left(\mathrm{x}^{\mathrm{t}+1}, \mathrm{y}^{\mathrm{t}+1}\right)}{\mathrm{d}^{\mathrm{t}}\left(\mathrm{x}^{\mathrm{t}}, \mathrm{y}^{\mathrm{t}}\right)} \times \frac{\mathrm{d}^{\mathrm{t}+1}\left(\mathrm{x}^{\mathrm{t}+1}, \mathrm{y}^{\mathrm{t}+1}\right)}{\mathrm{d}^{\mathrm{t}+1}\left(\mathrm{x}^{\mathrm{t}}, \mathrm{y}^{\mathrm{t}}\right)}\right]^{1 / 2}
$$

Equation (2) can be re-written to account for three important components of the MPI in the case of variable returns which makes it possible to measure scale efficiency (SE): the efficiency change index (EC), which indicates the change in technical efficiency between two adjacent periods; the technical change index (TC), which indicates the frontier shift and is called technological change; and the scale efficiency change (SEC), which measures the scale of operation:

$$
\begin{aligned}
\operatorname{MPI}\left(x^{t+1}, y^{t+1}, x^{t}, y^{t}\right)= & \underbrace{\frac{d_{v}{ }^{t+1}\left(x^{t+1}, y^{t+1}\right)}{d_{v_{v}}{ }^{t}\left(x^{t}, y^{t}\right)} \times[\underbrace{\left[\frac{d_{v}{ }^{t}\left(x^{t}, y^{t}\right)}{d_{v}{ }^{t+1}\left(x^{t+1}, y^{t+1}\right)} \times \frac{d_{c}{ }^{t+1}\left(x^{t+1}, y^{t+1}\right)}{d_{c}{ }^{t}\left(x^{t}, y^{t}\right)}\right]}_{\text {TEC }}}_{\text {EC }} \\
& \times \underbrace{\left[\frac{d_{c}{ }^{t}\left(x^{t}, y^{t}\right)}{d_{c}{ }^{t+1}\left(x^{t}, y^{t}\right)} \times \frac{d_{c}{ }^{t}\left(x^{t+1}, y^{t+1}\right)}{d_{c}{ }^{t+1}\left(x^{t+1}, y^{t+1}\right)}\right]}_{\text {TC }}
\end{aligned}
$$

where the $\mathrm{v}$ superscript refers to the variable return to scale (VRS) frontier and the C superscript refers to the constant return to scale (CRS) frontier. It is now relevant to interpret growth or decline according to these measures of productivity. If the estimated value of MPI, EC, TC or SEC is larger (or smaller) than 1, an improvement (or deterioration) is indicated by the productivity index. The product of EC and SEC is the total technical efficiency change (TEC). In the section that follows, after presenting the data, we examine the efficiency and developments in MPI and components of TEC, TC and SEC across the period studied for all considered ports.

\section{The data}

Because Norway is sparsely populated, its container ports, distributed across the country, are relatively small. Consequently, vessels that call at these ports are relatively small and are the feeder type, whereas the deep sea container ships are seldom at these ports. Therefore, small- and medium-sized ports that can mainly be categorised as gateway container ports are included in this study, in contrast to the large hub-ports that are more frequent in the literature. Given that the Norwegian ports of this type are relatively few in number, and because it is of interest to benchmark the Norwegian ports to comparable foreign ports, we included comparable gateway ports from the Nordic countries and the UK. Schøyen and Odeck (2013) analysed the technical efficiency of Norwegian container ports for the period 2002-2008. This paper, to the contrary, extends that paper by considering the period 2009-2014, by reviewing the literature on DEA-based MPI studies on seaports and by analysing MPI decomposition, emphasising changes in technology, efficiency and scale of operations.

The data were obtained from port authorities, terminal operators and port statistics, by e-mail, telephone and through internet. In the panel data collection process, we presented the data for the period 2002-2008 to each port's or terminal's administration for their update data for the period 2009-2014 and for their remarks and rectifications. The 
container ports identified in Schøyen and Odeck (2013) and also analysed in this study include six Norwegian (Oslo, Borg, Moss, Larvik, Ålesund and Kristiansand), three Swedish (Gothenburg, Stockholm and Helsingborg), three Danish (Aarhus, Aalborg and Fredricia), one Icelandic (Reykjavik), four Finnish (Helsinki, Turku, Rauma and HaminaKotka) and three UK ports (Southampton, Immingham and Grangemouth). In Finland the two ports of Hamina and Kotka merged into one company in 2011, with the new name Port of HaminaKotka Ltd, and therefore from 2011 onwards the port authorities had the policy to inform only overall data for the merged port. Therefore Hamina and Kotka are dealt with as one port also for the years 2009-2010 in the dataset in this study, simply by adding the values of each of the input and output variables. In total, 20 container ports were considered, and six years of annual data from 2009 to 2014 were collected for each port. The sampled ports are mainly gateway ports (not sea to sea transhipment hubs) and constitute a common container transport system in the North and Baltic Sea. The purpose of including 20 ports from the Nordic countries and UK in the dataset instead of limiting the number to just the six Norwegian ports is to increase the discrimination power of the analysis and to perform statistical tests in order to detect differences in MPI between the Norwegian ports and the other ports. Figure 2 is a map over Southern Norway showing the location of the county's six principal container ports, which are included in the sample in this study.

Figure 2 Map over the location of the principal container ports in Southern Norway (see online version for colours)

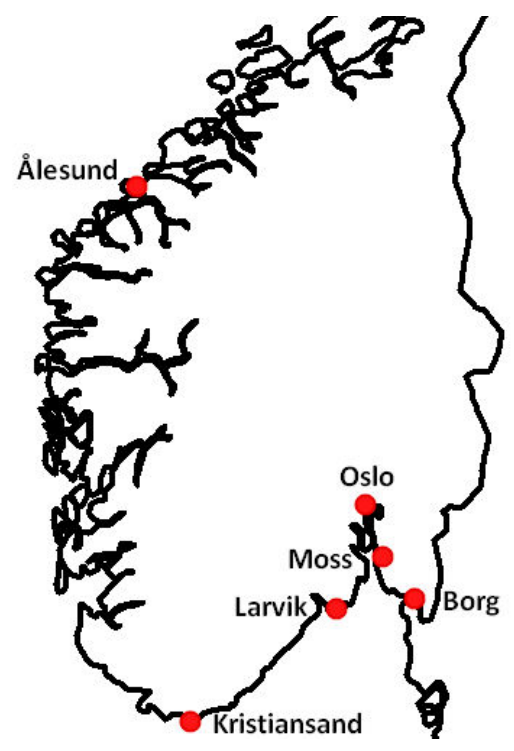

To 'clean' the data, information on the output and input values were presented to each port administration, seeking their verification and supplementary information. The responses contributed to the adjustment and addition of the data collected from secondary sources through internet.

The next question to be addressed was which variables to use as outputs and inputs. Container units (TEU) per port were identified as the appropriate output measure (see for instance Cullinane and Song, 2006). Input variables selected included the berth length, 
terminal areas, number of yard gantry cranes, straddle carriers and container handling trucks. The summary of variables through the study period are presented in Table 1 . There is great variation in the usage of the different types of equipment.

Table 1 Summary of variables used in the analysis

\begin{tabular}{|c|c|c|c|c|c|c|}
\hline \multicolumn{6}{|c|}{ Inputs } & \multirow{2}{*}{$\begin{array}{c}\text { Output } \\
\text { Container } \\
\text { throughput }\end{array}$} \\
\hline Variable name & $\begin{array}{l}\text { Berth } \\
\text { length }\end{array}$ & $\begin{array}{l}\text { Terminal } \\
\text { area }\end{array}$ & $\begin{array}{l}\text { Yard } \\
\text { gantry } \\
\text { cranes }\end{array}$ & $\begin{array}{l}\text { Straddle } \\
\text { carriers }\end{array}$ & $\begin{array}{l}\text { Container } \\
\text { handling } \\
\text { trucks }\end{array}$ & \\
\hline Unit of measurement & $m$ & $m 2$ & Number & Number & Number & TEU/year \\
\hline Average & 920 & 277,509 & 0.6 & 11.6 & 9.4 & 276860 \\
\hline $\operatorname{Max}$ & 2,792 & $1,000,717$ & 4.0 & 90.0 & 27.0 & 1830792 \\
\hline Min & 140 & 15,000 & 0.0 & 0.0 & 3.0 & 1884 \\
\hline S.D. & 673 & 292,894 & 1.2 & 21.3 & 5.6 & 362582 \\
\hline
\end{tabular}

Two general comments are in order with regards to the inputs used. First, the number of quay cranes is important and should be considered as an input. However, an initial assessment proved that the coefficient of correlation between the number of quay cranes and terminal area $\left(\mathrm{m}^{2}\right)$ was too high at 0.92 ; therefore, the number of quay cranes was excluded as an input variable in the final analysis. Second, because most of the input variables may be considered as proxies for capital, a variable for labour input should have been included. However, as has been pointed out in the literature of container port production and efficiency (see De Neufville and Tsunokawa, 1981; Wang et al., 2005; González and Trujillo, 2009), this variable is both difficult to obtain and unreliable in the available data, and there is a fairly stable and close relationship between the facilities (e.g., amount of equipment) and the number of dock workers. Thus, we assumed that the capital inputs incorporate a measure of the labour input. However, given the rapid development of new technologies, such as automated container handling equipment, advanced terminals are able to use lower levels of labour than other terminals. Thus, the results derived here should be interpreted with care.

\section{Empirical results}

Before presenting the empirical results, it is worthwhile to consider whether container ports should be evaluated from input minimisation, from output maximisation or from both points of view. Another issue to address is whether the analysis should be conducted under the assumption of CRS or VRS. These two issues are not simple ones. The answer to the first issue will depend on the objective of the study, i.e., whether ports are to be considered as input minimisers or output maximisers. Recognising that both are the objectives of the individual ports, in this study, we are interested in studying how ports are able to utilise their limited resources efficiently; thus, we evaluate ports from the input minimisation point of view. Regarding the second issue, the assumption should not matter. However, if the scale of an operation's impacts on efficiency is to be considered, both CRS and VRS efficiency scores must be calculated. Thus, in what follows, we present the results of both CRS and VRS when analysing efficiency and, when analysing 
productivity, we assume VRS for the simple reason that we want to know the role that scale efficiency plays in productivity progress or regress ${ }^{1}$.

The results of the analysis are presented in the following order:

1 the efficiency of ports

2 the productivity indices of ports using the MPI

3 a comparison of Norwegian ports relative to international ports in terms of productivity growth.

\subsection{Efficiency of container ports}

The efficiency scores under the VRS and CRS assumptions are presented in Table 2. All the efficiency scores were measured relative to the frontier of the same year. The scores for Norwegian ports are shown on the upper part of the table. The mean potential for input savings are at the intervals $[2 \% ; 5 \%]$ and $[9 \% ; 12 \%]$ for VRS and CRS, respectively. These results indicate that the means have fluctuated over the years of observation, and as expected, the VRS potential for input savings are lower than the CRS potential. In comparing the Norwegian ports to each other, the ports of Kristiansand and Larvik are the most efficient and both obtained scores of $100 \%$ irrespective of whether VRS or CRS is considered. Runner-up is the port of Moss and who obtain efficiency scores of $100 \%$ when VRS is considered and in only two incidences does it obtain scores below $100 \%$ but well above $90 \%$ when CRS is considered. Norwegian ports generally perform relatively well compared to the constructed annual frontiers since the average efficiency scores are high. From the column in Table 2 that report the standard deviations, it is observed that the Norwegian ports compared to the foreign ones on average have lower VRS-score fluctuations and higher CRS-score fluctuations. The reasons for these fluctuations are hard to explain.

Next, compare the performance of Norwegian ports to the international ports in Table 2. Reviewing the means for each country and across all years, the Norwegian ports, on average, perform better than all other Nordic nations in the dataset and are only outperformed by the UK ports. This performance must be good news for Norwegian port authorities. A panel-based statistical test for the differences in efficiency scores between Norwegian ports and all other international ports in the dataset revealed that the efficiency scores for Norwegian ports were significantly higher than the Nordic ones but not different from the UK ones. In terms of scale efficiency, which can be calculated by dividing the CRS-scores by VRS-scores, most of the ports in the dataset were operating with VRS and are therefore scale inefficient. If the ratio is equal to 1, the port is scale efficient; if the ratio is less than 1 , the port is operating under either increasing or decreasing returns to scale. This result is not reported in Table 2 due to space, but is evident in the table as VRS scores are higher than the CRS ones. Notably, Larvik and Kristiansand were fully scale efficient throughout the observed period.

With regards to the performance of individual ports, some explanations are available for the observed fluctuation in efficiency scores among the Norwegian ports. One example is Oslo, the largest container port in Norway in respect of container throughput. In January 2008, the first stage of the new Sjursøya Container Terminal (SCT) in the Port of Oslo was opened. The SCT was planned to replace the Filipstad Container Terminal (FCT). Due to terminal operational challenges, especially with regard to the handling and 
storage of empty containers, both SCT and FCT were in operation for most of 2008. The operations at FCT were only terminated at the end of that year. Consequently, this circumstance increased Oslo's operational costs for 2008. Combined with a 3\% decrease in annual container throughput from 2007 to 2008, these developments were carried on to the next full year of operation in 2009 and led to low relative efficiency score for Oslo at 0.86 in 2009. After 2009 as evident in Table 2, the efficiency scores with respect to VRS increased in the subsequent years to about $100 \%$ and dropped to $94 \%$ in the final year of 2014.

\subsection{Productivity changes of container ports}

The next issue of major interest is to investigate how Norwegian ports improve their productivity from one period to the next compared to other comparable container ports in the Nordic countries and the UK. Table 3 presents the results of the input-based Malmquist productivity indices calculated according to Equation (3) for the entire period on average and where only the TC, EC and MPI are reported. VRS is assumed to be able to measure the impact of the scale efficiency of productivities. Values of MPIs greater than 1 imply progress (productivity growth) and values less than 1 imply a productivity decline.

Several observations can be made from Table 3. First, from the columns that report the total productivity measure, indicated as MPI, it is observed that while some ports experience progress, others experience regress, which indicates great fluctuations in MPIs across the periods studied. With regards to the grand geometric mean of MPIs, however, regresses are observed only in the two final periods of 2012-2013 and 2013-2014 (productivity regress of about $4.3 \%$ and $1.0 \%$, respectively). For the periods in between 2009 and 2012, there has been progress in the interval [0.3\%; 6.3\%]. Overall, progress across the periods is more pronounced than regress.

Second, the question of which of the two major components of MPI explains the observed results, technical change (TC), efficiency change (EC) or both is addressed. A closer examination of Table 3 reveals that in the first two periods of 2009-2010 and 2010-2011, total productivity progress, as measured by MPI was mainly due to strong progress in TC among ports. This progress with regards to TC may be explained by the fact that at this stage of the reformation period in the container port industry in Europe, the sampled ports adopted new technologies to improve their performances. Later, as is evident in the results of the succeeding period of 2011-2012, after fully utilising the technologies available, ports on average reverted to improving their total productivities (MPIs) by improving their technical efficiencies. For the period 2012-2013 on average, the sampled ports regressed in both TC and EC, resulting into MPI regress of $4.3 \%$. Notably, the Norwegian ports for the same period had no change in TC $(0.996 \approx 1)$ and showed, together with the Swedish ports, an average progress in efficiency change (EC). The Finnish, Danish and UK ports all had a regress in efficiency change. In the final period from 2013-2014, the sampled ports, on average, once again adopted new technologies (technical change of about $8.0 \%$ ) rather than technical efficiency improvements to increase productivity. Thus, overall there have been some pronounced fluctuations with regards to all components of the MPI. 
Table 2 VRS and CRS efficiency scores for the period 2009-2014

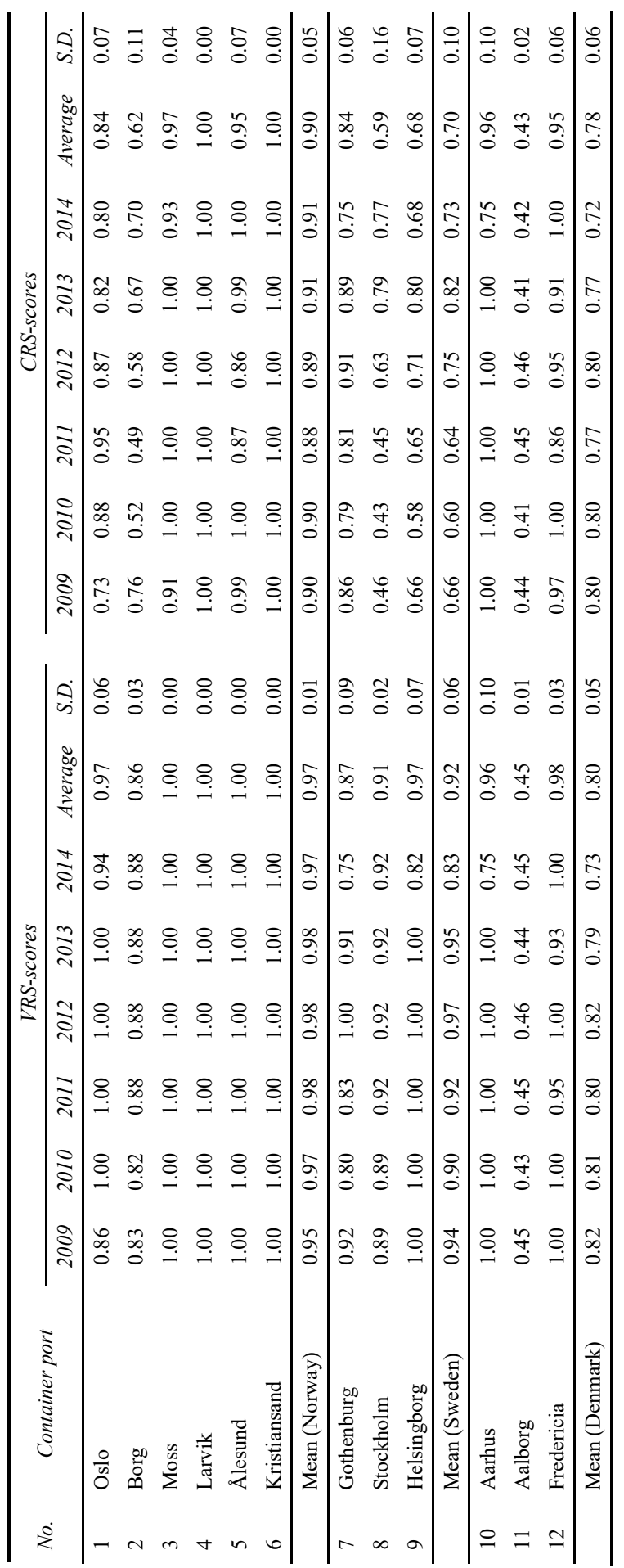


Table 2 VRS and CRS efficiency scores for the period 2009-2014 (continued)

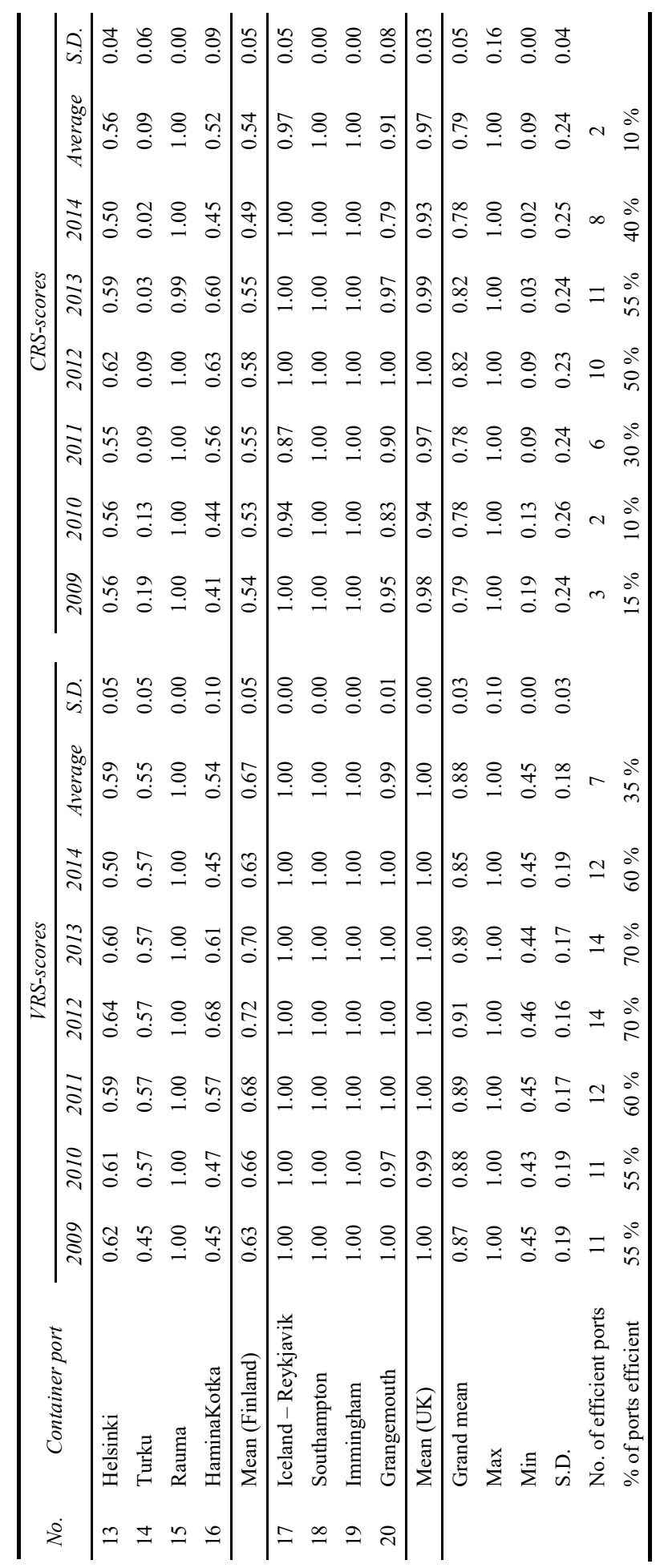


Table 3 Malmquist input-based productivity indices by year

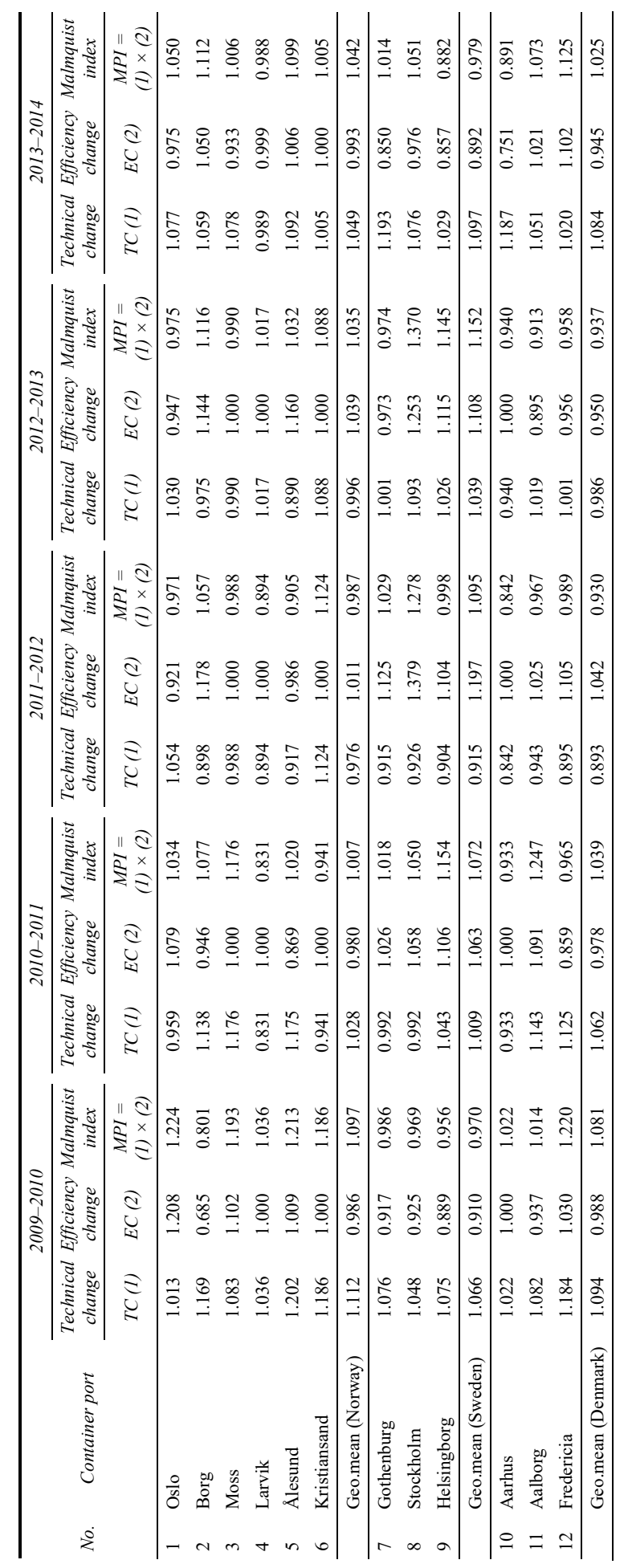


Table 3 Malmquist input-based productivity indices by year (continued)

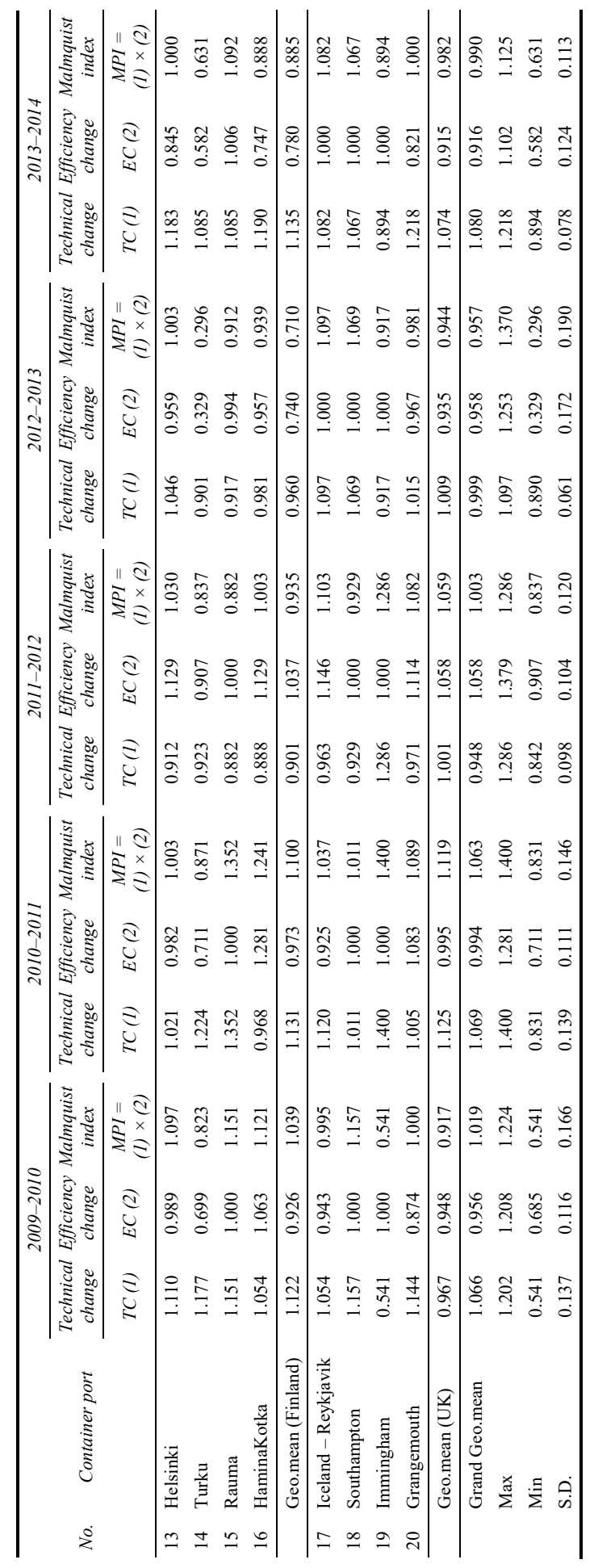


Table 4 Malmquist input-based productivity indices and decompositions

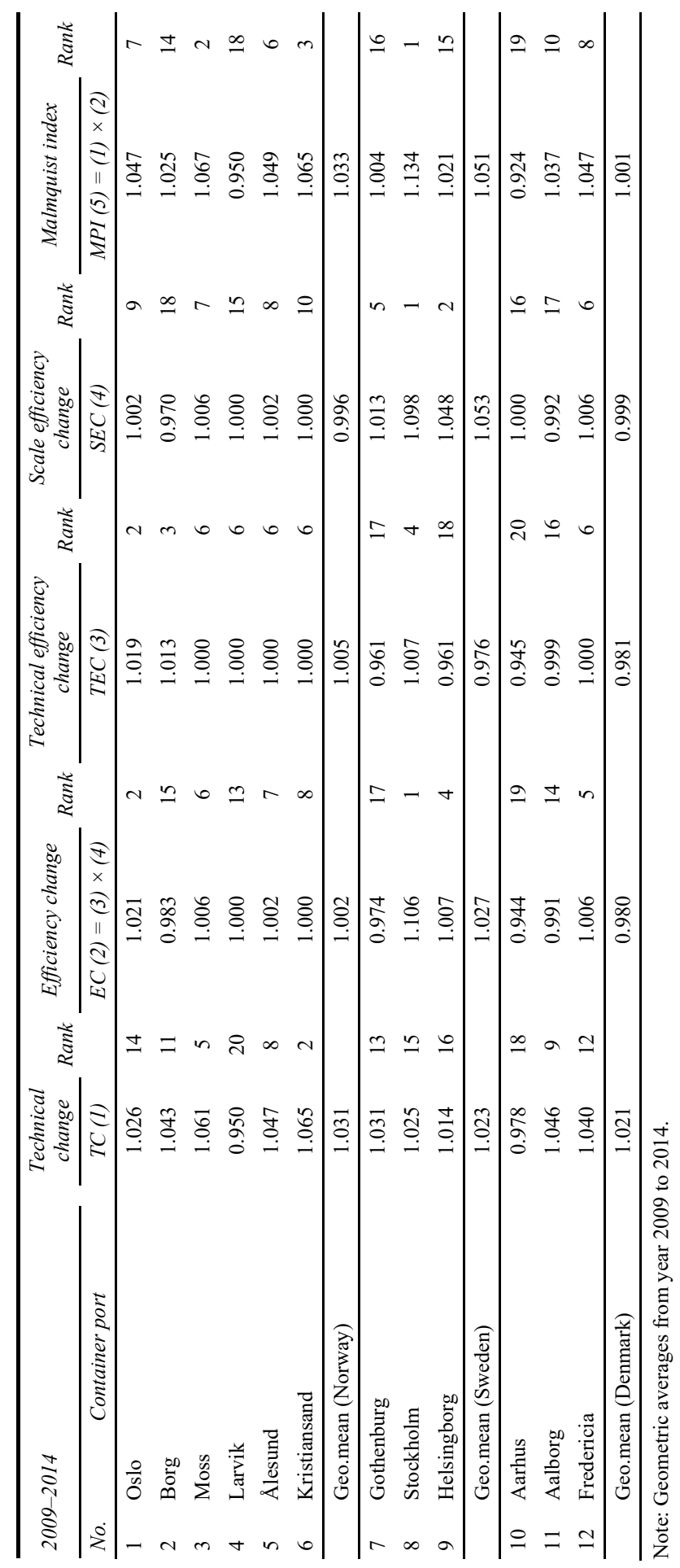


Table 4 Malmquist input-based productivity indices and decompositions (continued)

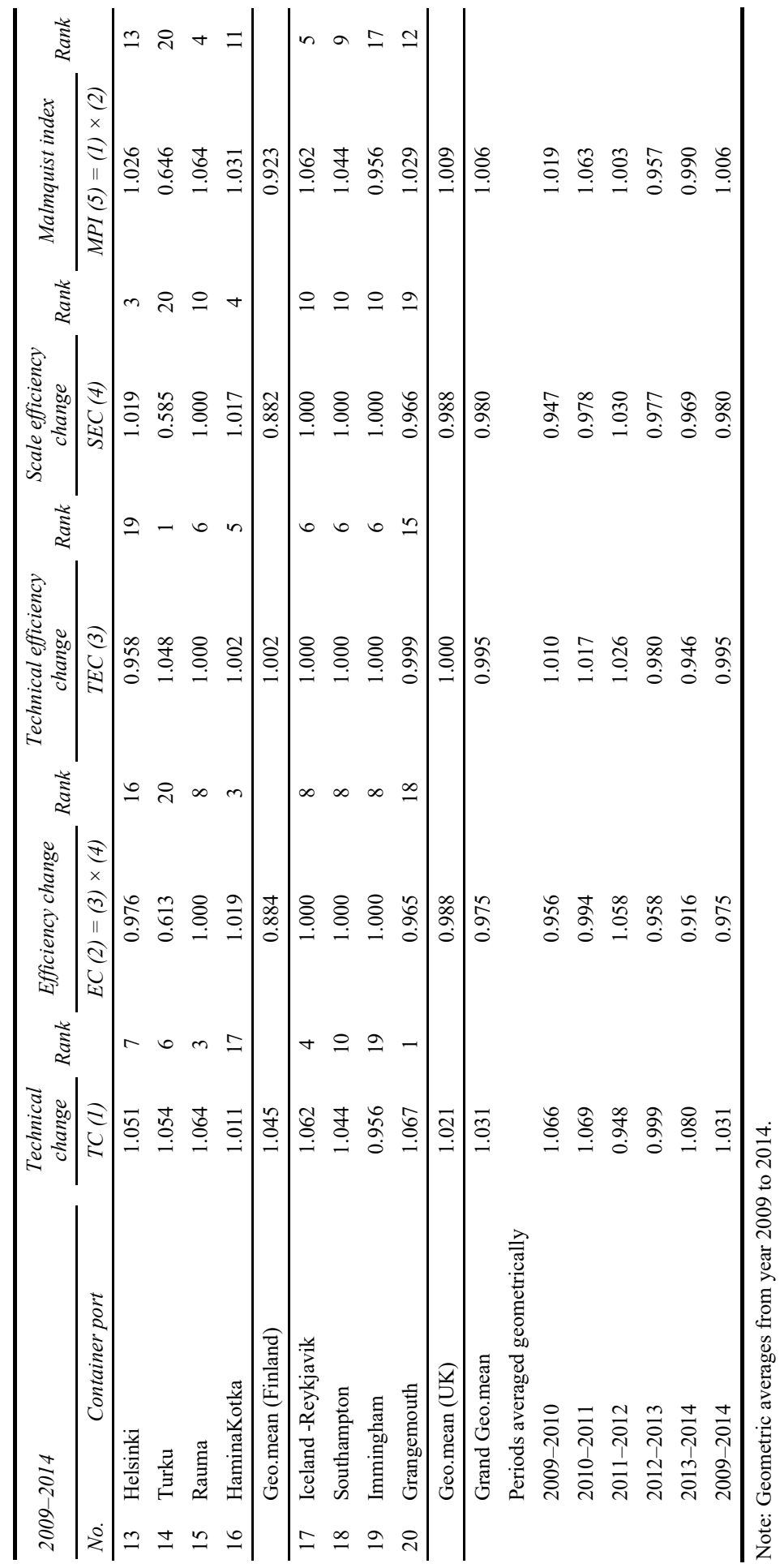


To understand these observations, it is relevant to relate them to one or more of the ports. For instance, the port of Oslo experienced productivity progress (MPI $>1$ ) during the periods 2009-2010, 2010-2011 and 2011-2012 and a regress (MPI < 1) 2012-2013, 2013-2014. Additionally, Oslo experienced a TC growth over all periods 2009-2014 except from 2010-2011. In the first two periods constituting 2009-2011, Oslo displayed a positive catching-up effort, and in that case, the improvements were the formidable values of $20.8 \%$ (2009-2010) and 7.9\% (2010-2011). Also interesting are the cases of Larvik and Kristiansand, which both experienced no progress in efficiency change any of the periods considered. Therefore, for these two ports all overall productivity changes (MPI) over the period studied was due to progress in technical change.

The mean indices by ports across all periods studied are shown in Table 4 . The mean MPI for the entire sample shows $0.6 \%$ progress, indicating only a small productivity progress for the average port. Further, in Table 4, the ports' mean MPIs are ranked from best (Stockholm) to worst (Turku). The Norwegian ports' MPI ranks are between 1 (Moss) and 18 (Larvik), and four of the six Norwegian ports are among the top 10. Next, we consider columns 1 and 2, which show TC and EC, respectively. Overall, TC annually rose by $3.1 \%$ while the EC annually regressed by $2.5 \%$. Columns 3 and 4 show the decompositions of ECs. On average, for 20 ports, SEC was more influential (20\% regress annually) than TEC ( $0.5 \%$ regress). Next, the port with the lowest technical development was Larvik, with a $5.0 \%$ regress $(\mathrm{TC}=0.950)$, while 17 of the 20 ports have TC indices exceeding 1. All other Norwegian port than Larvik on average showed technological improvement $(\mathrm{TC}>1)$ during the period studied. Further, the EC indices are larger than 1 for 13 ports. This finding suggests that the other seven ports did not progress in input-saving technical efficiency in their container operations. Borg on average annually regressed $1.7 \%$ in efficiency change, while the five other Norwegian on average improved their efficiency change indices. Further, consider Oslo as an example. This port experienced a progress for all indices throughput the period studied, which mirrored its MPI progress of $4.7 \%$. Oslo's EC (2.1\% progress and overall rank number 2$)$ is more explained by pure technical efficiency change $(\mathrm{TEC}=1.9 \%)$ than by scaling their operations $(\mathrm{SEC}=0.2 \%)$. As a consequence, its MPI ranks number 7 . Another example is Grangemouth which is recognised in Table 4 with a TC value of $6.7 \%$ progress (ranked number 1), but failed with both technical efficiency developments and in scaling their operations (TEC 1\% regress and SEC 3.3\% regress). This means that the investments in new technology and system are responsible for the $2.7 \%$ productivity progress (MPI) concurrent with lagging in their efficient use of these new technologies and systems compared to the other ports in the sample. Stockholm was the only port showing a double-digit annual overall productivity growth, with a MPI number of 1.134. The SEC number was 1.098 (ranked number 1), which means Stockholm was particularly successful in scaling up their operations. Swedish ports as a group had a SEC number of 1.053, which shows they were on average successful in scaling their operations. Larvik, which, as informed above, was ranked number 20 with respect to TC but was fully scale efficient throughout all six periods (Table 2), did not achieve any pure technical efficiency improvements (TEC) over the period, and thus was ranked as number 18 with respect to MPI. Thus, Larvik failed to adopt technology changes but succeeded in remaining fully scale efficient in their operations, which combined led to an annual $5.0 \%$ productivity regress. Larvik, by ranking as number 18 in the sample, is then the worst performer among the Norwegian ports (see column 5) with regards to MPI. The Larvik case can possibly be explained by how its port owners and managers seemingly 
prioritised and were successful in scale adjustments as the container traffic volumes fluctuated, rather than long-term investments in technology. In contrasts, the Finnish port Turku, which experienced declining container volumes over the period studied, regressed with $61.5 \%$ in their scale efficiency, and thus failed in scaling down their size of operations. The mean MPI for Norwegian ports is 1.033. This number represents a $3.3 \%$ productivity progress over the six-year period. Notably, the average indices (TC, EC, TEC and SEC) for Norwegian ports as a group are above averages for the sample.

Some general observations with regards to the productivity of ports in the sample are:

1 the average port slightly progressed in productivity in the period studied

2 the means of the different components of MPI show progress for technological investments and a decline for pure technical efficiency and scale efficiency, but there is great variation across individual ports

3 on average, the Norwegian ports as a group are above average among all sampled ports in terms of overall productivity performance, due to progress in both efficiency and technological innovations.

On average, the Norwegian ports are at average in technical change across the period studied. These differences in results are, however, merely observations and have not been subjected to statistical tests.

\subsection{Are Norwegian container ports improving more in productivity than their Nordic and UK counterparts?}

An objective of this paper has been to address the efficiency and productivity of Norwegian ports as compared to their peers in the Nordic countries and the UK. So far, there have been indications that they perform as well as their peers in terms of efficiency scores and worse than their peers in terms of productivity progress/regress. To reach a definitive conclusion with regards to the latter, we subjected the results to statistical tests.

We tested whether there are any statistically significant differences in the mean productivity indices, TC, TEC, SEC and MPI, between the Norwegian ports as a group and the other ports as second group. We used the median test as well as the Mann-Whitey test, which compares the distributions of the indices for each of the two groups. The Mann-Whitney test has been suggested as the appropriate test of differences for DEA-based studies (see for instance Grosskopf and Valdmanis, 1987). We also applied the Kolmogorov-Smirnov test, as recommended by Banker and Natarajan (2004), to gauge whether the two groups' underlying probability distributions differ. The null hypothesis in the median test is that the mean indices across the two port groups are identical. The null hypothesis in the Mann-Whitney and Kolmogorov-Smirnov tests are that the distribution of the mean indices values across the two groups are identical. The test statistics ${ }^{2}$, with a very high $p$-value across the methods, indicate that there are not significant differences in mean MPIs, TCs, TECs and SECs. The uppermost part of Table 5 reveals that, on average, the Norwegian ports progressed in total productivity, as measured by MPI, by approximately $3.3 \%$. Further, because technical change progressed by approximately $3.1 \%$, much of the observed progress in total productivity is because the Norwegian ports were successful to adopt new technologies to improve their productivities. All the test of differences between Norwegian ports versus other ports 
shows that the null hypothesis cannot be rejected; Norwegian ports are not overperformers as compared to their peers in the Nordic countries and the UK.

Table 5 Non-parametric statistical tests of the difference in MPI indices between Norwegian and other ports

\begin{tabular}{|c|c|c|c|c|c|c|c|c|}
\hline & \multicolumn{2}{|c|}{$\begin{array}{l}\text { Technical } \\
\text { change (TC) }\end{array}$} & \multicolumn{2}{|c|}{$\begin{array}{c}\text { Technical } \\
\text { efficiency } \\
\text { change (TEC) }\end{array}$} & \multicolumn{2}{|c|}{$\begin{array}{c}\text { Scale } \\
\text { efficiency } \\
\text { change (SEC) }\end{array}$} & \multicolumn{2}{|c|}{$\begin{array}{l}\text { Malmquist } \\
\text { index (MPI) }\end{array}$} \\
\hline & Norwegian & Others & Norwegian & Others & Norwegian & Others & Norwegian & Others \\
\hline & $\begin{array}{c}2009 \\
2014\end{array}$ & $\begin{array}{c}2009- \\
2014\end{array}$ & $\begin{array}{c}2009 \\
2014\end{array}$ & $\begin{array}{c}2009 \\
2014\end{array}$ & $\begin{array}{c}2009 \\
2014\end{array}$ & $\begin{array}{c}2009 \\
2014\end{array}$ & $\begin{array}{c}2009 \\
2014\end{array}$ & $\begin{array}{c}2009 \\
2014\end{array}$ \\
\hline $\begin{array}{l}\text { Number } \\
\text { of ports }\end{array}$ & 6 & 14 & 6 & 14 & 6 & 14 & 6 & 14 \\
\hline $\begin{array}{l}\text { Number of } \\
\text { observations }\end{array}$ & $\begin{array}{l}5 \cdot 6 \\
=30\end{array}$ & $\begin{array}{l}5 \cdot 14 \\
=70\end{array}$ & $\begin{array}{l}5 \cdot 6 \\
=30\end{array}$ & $\begin{array}{l}5 \cdot 14 \\
=70\end{array}$ & $\begin{array}{l}5 \cdot 6 \\
=30\end{array}$ & $\begin{array}{l}5 \cdot 14 \\
=70\end{array}$ & $\begin{array}{l}5 \cdot 6 \\
=30\end{array}$ & $\begin{array}{l}5 \cdot 14 \\
=70\end{array}$ \\
\hline Median & 1.033 & 1.036 & 1.000 & 1.000 & 1.000 & 1.000 & 1.033 & 1.003 \\
\hline $\begin{array}{l}\text { Geometric } \\
\text { mean }\end{array}$ & 1.031 & 1.031 & 1.005 & 0.991 & 0.996 & 0.973 & 1.033 & 0.994 \\
\hline Variance & 0.010 & 0.017 & 0.001 & 0.007 & 0.008 & 0.019 & 0.011 & 0.029 \\
\hline \multicolumn{9}{|l|}{ Tests results } \\
\hline Median & \multicolumn{2}{|c|}{$\begin{array}{l}\text { Retain the null } \\
\text { hypothesis }\end{array}$} & \multicolumn{2}{|c|}{$\begin{array}{l}\text { Retain the null } \\
\text { hypothesis }\end{array}$} & \multicolumn{2}{|c|}{$\begin{array}{l}\text { Retain the null } \\
\text { hypothesis }\end{array}$} & \multicolumn{2}{|c|}{$\begin{array}{l}\text { Retain the null } \\
\text { hypothesis }\end{array}$} \\
\hline $\begin{array}{l}\text { Wilcoxon- } \\
\text { Mann- } \\
\text { Whitney }\end{array}$ & \multicolumn{2}{|c|}{$\mathrm{U}=1036.0$} & \multicolumn{2}{|c|}{$\mathrm{U}=994.0$} & \multicolumn{2}{|c|}{$\mathrm{U}=1038.0$} & \multicolumn{2}{|c|}{$\mathrm{U}=914.0$} \\
\hline $\begin{array}{l}\text { Two-sample } \\
\text { rank-sum test }\end{array}$ & \multicolumn{2}{|c|}{$\begin{array}{c}z=-0.105 \\
(0.916)\end{array}$} & \multicolumn{2}{|c|}{$\begin{array}{l}\mathrm{z}=-0.495 \\
(0.621)\end{array}$} & \multicolumn{2}{|c|}{$\begin{array}{c}\mathrm{z}=-0.092 \\
(0.927)\end{array}$} & \multicolumn{2}{|c|}{$\begin{array}{c}\mathrm{z}=-1.023 \\
(0.306)\end{array}$} \\
\hline $\begin{array}{l}\text { Kolmogorov- } \\
\text { Smirnov test }\end{array}$ & \multicolumn{2}{|c|}{$\begin{array}{c}z=0.415 \\
(0.995)\end{array}$} & \multicolumn{2}{|c|}{$\begin{array}{c}z=0.895 \\
(0.400)\end{array}$} & \multicolumn{2}{|c|}{$\begin{array}{c}z=0.480 \\
(0.975)\end{array}$} & \multicolumn{2}{|c|}{$\begin{array}{c}z=0.829 \\
(0.497)\end{array}$} \\
\hline
\end{tabular}

Note: $p$-values in parentheses.

\section{Conclusions and implications}

This paper applies a DEA-based MPI to measure the productivity of container gateway ports in Norway compared to similar ports in the Nordic countries and the UK. We have addressed several questions, e.g., the magnitude of progress or regress in productivity for the entire sector and whether the productivity performance of Norwegian ports differs from that of others.

Our conclusions are as follows:

1 Overall, and for the average port considered, there has been an annual productivity increase of approximately $0.6 \%$. The average productivity growth is due to technical gains (investing in new technology and systems) and not technical efficiency change (catching-up), which was regressing. A probable explanation for the productivity growth is the pressure that has been exerted on ports to improve their performance 
due to increased container traffic for most of the ports in the sample in the observed period.

2 Among the Norwegian ports, five progressed in productivity, and one regressed. Oslo, being ranked as number 7 in the sample, showed an above average productivity improvement compared to both the other Norwegian port and the foreign ones.

3 There is no statistical evidence that there are differences in productivity performance between Norwegian ports as one group and ports in the Nordic countries and the UK as the second group.

The main contribution of this paper is that it is the first to consider productivity indices of the Norwegian seaport industry. This study has provided Norwegian decision makers with new information regarding the performance of Norway's container port industry compared to the international port industry. Specifically, this study provides information on which ports performs poorly and hence require more attention. Observing the impact of each productivity indices on productivity change estimates is of great significance to policy makers and corporate decision makers, because the source of productivity change is identified. For instance, it would be a waste of resources if a port or a terminal were unable to make efficient use of its existing production facilities or were unable to adjust its scale of operations, ascribing instead its inferior productivity change to technological deficiencies, and erroneously continued with a technological investment program.

However, the presented efficiency and productivity indices should not be interpreted uncritically, as there is bound to be noise in the data and there may be external factors that were not included in the analysis. Regarding the former, the data are fairly 'clean', as they were counter-checked with port operators. Thus, one future area of potential studies is to detect qualitative internal factors for inefficiency and productivity regress, and to identify possible external factors (e.g. differences in ownership and governance models) that may impact efficiency and productivity, and include them in a study. Another possible future extension in the container port productivity context is to apply different approaches to the same dataset, thus triangulating the findings and exploring the validity of the approaches.

\section{References}

Al-Eraqi, A.S., Khader, A.T. and Mustafa, A. (2009) 'DEA Malmquist index measurement in Middle East and East African containers terminals', International Journal of Shipping and Transport Logistics, Vol. 1, No. 3, pp.249-259.

Banker, R.D. and Natarajan, R. (2004) Statistical tests based on DEA efficiency scores', in Cooper, W.W., Seiford, L.M. and Zhu, J. (Eds.): Handbook on Data Envelopment Analysis, Chapter 11, Springer Science + Business Media, LLC, New York, USA.

Barros, C.P., Haralambides, H., Hussain, M. and Peypoch, N. (2011) Seaport efficiency and productivity growth', in Cullinane, K. (Ed.): International Handbook of Maritime Economics, Chapter 17, Edward Elgar, London.

Cheon, S., Dowall, D.E. and Song, D-W. (2009) 'Typology of long-term port efficiency improvement paths: Malmquist total factor productivity for world container ports', Journal of Infrastructure Systems, Vol. 15, No. 4, p.340. 
Cheon, S., Dowall, D.E. and Song, D-W. (2010) 'Evaluating impacts of institutional reforms on port efficiency changes: ownership, corporate structure, and total factor productivity changes of world container ports', Transportation Research Part E: Logistics and Transportation Review, Vol. 46, No. 4, pp.546-561.

Coelli, T.J. (1996) A Guide to FRONTIER Version 4.1: A Computer Program for Stochastic Frontier Production and Cost Function Estimation, Centre for Efficiency and Productivity Analysis (CEPA) Working Paper, 96 (07).

Cullinane, K. and Song, D-W. (2006) 'Estimating the relative efficiency of European container ports: a stochastic Frontier analysis', in Cullinane, K. and Talley, W.K. (Eds.): Port Economics, Research in Transportation Economics, Vol. 16, pp.85-115, Elsevier, Amsterdam.

De Neufville, R. and Tsunokawa, K. (1981) 'Productivity and returns to scale of container ports', Maritime Policy and Management, Vol. 8, No. 2, pp.121-129.

Estache, A., de la Fé, B.T. and Trujillo, L. (2004) 'Sources of efficiency gains in port reform: a DEA decomposition of a Malmquist TFP index for Mexico', Utilities Policy, Vol. 12, No. 4, pp.221-230.

Färe, R., Grosskopf, S. and Lovell, C.A.K. (1994) Production Frontiers, Cambridge University Press, UK.

Fu, B-x., Song, X-q. and Guo, Z-j. (2009) 'DEA-based Malmquist productivity index measure of operating efficiencies: new insights with an application to container ports', Journal of Shanghai Jiaotong University (Science), Vol. 14, No. 4, pp.490-496.

González, M. and Trujillo, L. (2009) 'Efficiency measurement in the port industry: a survey of the empirical evidence', Journal of Transport Economics and Policy, Vol. 43, No. 2, pp.157-192.

Grosskopf, S. and Valdmanis, V. (1987) 'Measuring hospital performance: a non-parametric approach', Journal of Health Economics, Vol. 6, No. 2, pp.89-107.

Guerrero, C.A. and Rivera, T.C. (2009) 'Mexico: total productivity changes at the principal container ports', Cepal Review, No. 99, pp.173-185.

Haralambides, H., Hussain, M., Barros, C.P. and Peypoch, N. (2010) 'A new approach in benchmarking seaport efficiency and technological change', International Journal of Transport Economics, Vol. 27, No. 1, pp.77-96.

Lai, K-H., Ngai, E.W. and Cheng, T.C. (2002) 'Measures for evaluating supply chain performance in transport logistics', Transportation Research Part E: Logistics and Transportation Review, Vol. 38, No. 6, pp.439-456.

Liu, B-L., Liu, W-L. and Cheng, C-P. (2008) 'The efficiency of container terminals in mainland China: an application of DEA approach', 4th International Conference on Wireless Communications, Networking and Mobile Computing, WiCOM '08, 2008 IEEE Xplore Digital Library, pp.1-10.

Lozano, S. (2009) 'Estimating productivity growth of Spanish ports using a non-radial, non-oriented Malmquist index', International Journal of Shipping and Transport Logistics, Vol. 1, No. 3, pp.227-248.

Meeresman, H. and Van de Voorde, E. (2010) 'Port management, operations and competition: a focus on North Europe', in Grammenos, C.Th. (Ed.): The Handbook of Maritime Economics and Business, 2nd ed., pp.891-906, Lloyd's List, London.

Notteboom, T.E. (2010) 'Concentration and the formation of multi-port gateway regions in the European container port system: an update', Journal of Transport Geography, Vol. 18, No. 4, pp.567-583.

NTP (2010) Norwegian National Transport Plan 2010-2019, The Norwegian Ministry of Transport and Communications.

Odeck, J. and Bråthen, S. (2012) 'A meta-analysis of DEA and SFA studies of the technical efficiency of seaports: a comparison of fixed and random-effects regression models', Transportation Research Part A: Policy and Practice, Vol. 46, No. 10, pp.1574-1585. 
Panayides, P.M., Maxoulis, C.N., Wang, T-F. and Ng, K.Y.A. (2009) 'A critical analysis of DEA applications to seaport economic efficiency measurement', Transport Reviews, Vol. 29, No. 2 , pp.183-206.

Rodrigue, J-P., Comtois, C. and Slack, B. (2006) The Geography of Transport Systems, Routledge, London.

Schøyen, H. and Odeck, J. (2013) 'The technical efficiency of Norwegian container ports: a comparison to some Nordic and UK container ports using data envelopment analysis (DEA)', Maritime Economics \& Logistics, Vol. 15, No. 3, pp.197-221.

Song, B. and Cui, Y. (2014) 'Productivity changes in Chinese container terminals 2006-2011', Transport Policy, Vol. 35, pp.377-384.

Wang, T-F., Cullinane, K. and Song, D-W. (2005) Container Port Production and Economic Efficiency, Palgrave-Macmillan, New York.

Woo, S-H., Pettit, S. and Beresford, A. (2012) 'Seaport research: a decadal analysis of trends and themes since the 1980s', Transport Reviews, Vol. 32, No. 3, pp.351-377.

Woo, S-H., Pettit, S., Kwak, D-W. and Beresford, A. (2011) 'Seaport research: a structured literature review on methodological issues since the 1980s', Transportation Research Part A: Policy and Practice, Vol. 45, No. 7, pp.667-685.

Zhu, J. (2009) Quantitative Models for Performance Evaluation and Benchmarking: Data Envelopment Analysis with Spreadsheets, Springer Science + Business Media, LLC, New York, USA.

\section{Notes}

1 The software used to calculate the DEA efficiency scores and the MPIs in this paper is the DEA Frontier Add-In for Microsoft Excel 2007 (see Zhu, 2009).

2 The statistical tests were conducted in SPSS Statistics 19, and results are presented in Table 5. 